\title{
Creativity Creates Active Learning in The Limitations of Sarpras in The Learning Environment
}

\author{
Hindun Hindun ${ }^{1}$ \\ \{hindun@uinjkt.ac.id $\left.{ }^{1}\right\}$ \\ ${ }^{1}$ Universitas Islam Negeri Syarif Hidayatullah, Jakarta, Indonesia
}

\begin{abstract}
In the midst of the information age which is rapidly developing and requires that every individual is technologically literate, it turns out that some Indonesians are still trying their best to bring harmony to learning in class with students living in the millennial era.The purpose of this paper is to describe in concrete terms the real practice of learning in an environment with limited facilities and infrastructure, but the teacher still presents various learning media and methods for the implementation of active learning. The learning environment that is the object of this research is the learning conditions in "MTs Daarul Himmah, Bojongsari". Qualitative descriptive is a method used in this study with direct observation techniques. The results of this study convey to the reader that all the energy and competencies presented by a teacher in harmonizing learning in accordance with the existence of the conditions of the times and the lives of students become an effort that must always be seriously appreciated.
\end{abstract}

Keyword: Active Learning, Learning Environment, MTs Daarul Himmah.

\section{Introduction}

Life-long learning is words that are always remembered to express the message "Prophet Muhammad" about studying. Comfortable learning space is one indicator that is sought by every student guardian or parent to be able to entrust their children to study in an institution they trust. In addition to the physical or school buildings, the learning environment is directed towards the existence of peers who can create commendable behavior. Parents' concerns about some of the values that have been eroded by such complex conditions make each parent must be selective in determining their existence. Therefore, the term "Madrasah" is a trusted reference for the community to develop social relations in obtaining daily learning as a place of choice for schools for junior high school (JHS) or MTs (Madrasah Tsanawiyah) students.

Previous researchers who have studied the learning environment, among them are entitled "The Effect of Learning Environment and Achievement Motivation on Student Learning Outcomes" Competency in Industrial Automation Engineering in "Negeri 2 Vocational High School, Yogyakarta" by: Bayu Winarno from Yogyakarta State University, year 2012. The results of his research are that there is a positive and significant influence between the learning environment on the learning outcomes of students in the Industrial Automation Engineering skills competency in Yogyakarta State Vocational High School with a t count $>\mathrm{t}$ table (3.32> 1.68 ) and a contribution of $19.61 \%$; (2) there is a positive and significant influence between achievement motivation on the learning outcomes of the competency skills of "Industrial Automation Techniques in Yogyakarta State Vocational High School 2" with a value of $t$ count $>\mathrm{t}$ table $(2.74>1.68)$ and a contribution of $14.85 \%$; (3) there is a positive and significant influence between the learning environment and achievement motivation together on the 
learning outcomes of students' competency skills "Industrial Automation Techniques in Yogyakarta State Vocational High School 2" with a calculated F value $>$ F table $(14.99>3.17)$ and donations of $34.50 \%$.

Other research related to the learning environment which is in direct contact with the teacher's professional competency, entitled "Analysis of Professional Competence of Teachers in the District of Kampar in Riau Province" [1]. The results of his study showed that of 35 teachers who were tested with quantitative descriptive methods it was known that eight indicators in the professional competency category produced "low categories". The eight indicators are (1). Mastering the basic concepts of language as a means of development for each field of child development with a percentage value of $51.43 \%$. (2). Mastering the basic concepts of physical education as a means of development for each field of child development with a percentage of $46.67 \%$. (3). Mastering game tools for developing social emotional aspects of kindergarten / early childhood children with a percentage value of $58.57 \%$. (4). Understand the ability of kindergarten / early childhood children in each field of development with a percentage of $41.90 \%$. (5). Understand the progress of children in each field of development in kindergarten / early childhood with a percentage value of $54.29 \%$. (6). Processing material in the field of creative development in accordance with the level of development of students with a percentage value of $55.71 \%$. (7). Utilizing the results of reflection in order to increase professionalism with a percentage value of $45.71 \%$. (8). Conduct class action research to increase professionalism with a percentage value of $58.57 \%$.

The two studies above convey to the reader that the influence of the learning environment and professional competence of teachers has been studied even in certain areas or boundaries. The paper clearly provides information about the learning environment that is observed closely and directly in the form of creativity creates active learning.

\section{Research Method}

For more than two weeks the researchers conducted this research directly in the field through observations using instruments in the form of observations about "Learning Media Quality Indicators". This type of qualitative research is used as a reference to analyze the results of this study, as revealed by Moleong, that; "Qualitative research is research that intends to understand the phenomenon of what is experienced, for example regarding behavior, perceptions, motivations, actions, etc. holistically and in a descriptive way in the form of words and languages in a special context that is natural by utilizing various methods scientific", [2].

The data collection techniques with the following observation steps:

1. The researcher conducts a survey of the schools that will be carried out research

2. Researchers get to know the teachers who teach at the school

3. The researcher goes around observing the school environment and the surrounding community

4. The researcher asks the school to approve teaching the teacher in classroom learning practices

5. The researcher observed several times the teacher's face-to-face teaching and focus on the religious teacher named Hilman Arif (Born in Bandung, March 7, 1983) with the material "Al-Azhar Growth and Development" on Islamic Cultural History subjects.

The stages in the data collection techniques above are in line with those expressed [3], that "Observation is the most basic and oldest method, because through certain methods we 
can always be involved in the process of observing", [3]. The following is the form "Indicator Quality of Learning Media "as an instrument used by researchers in observation.

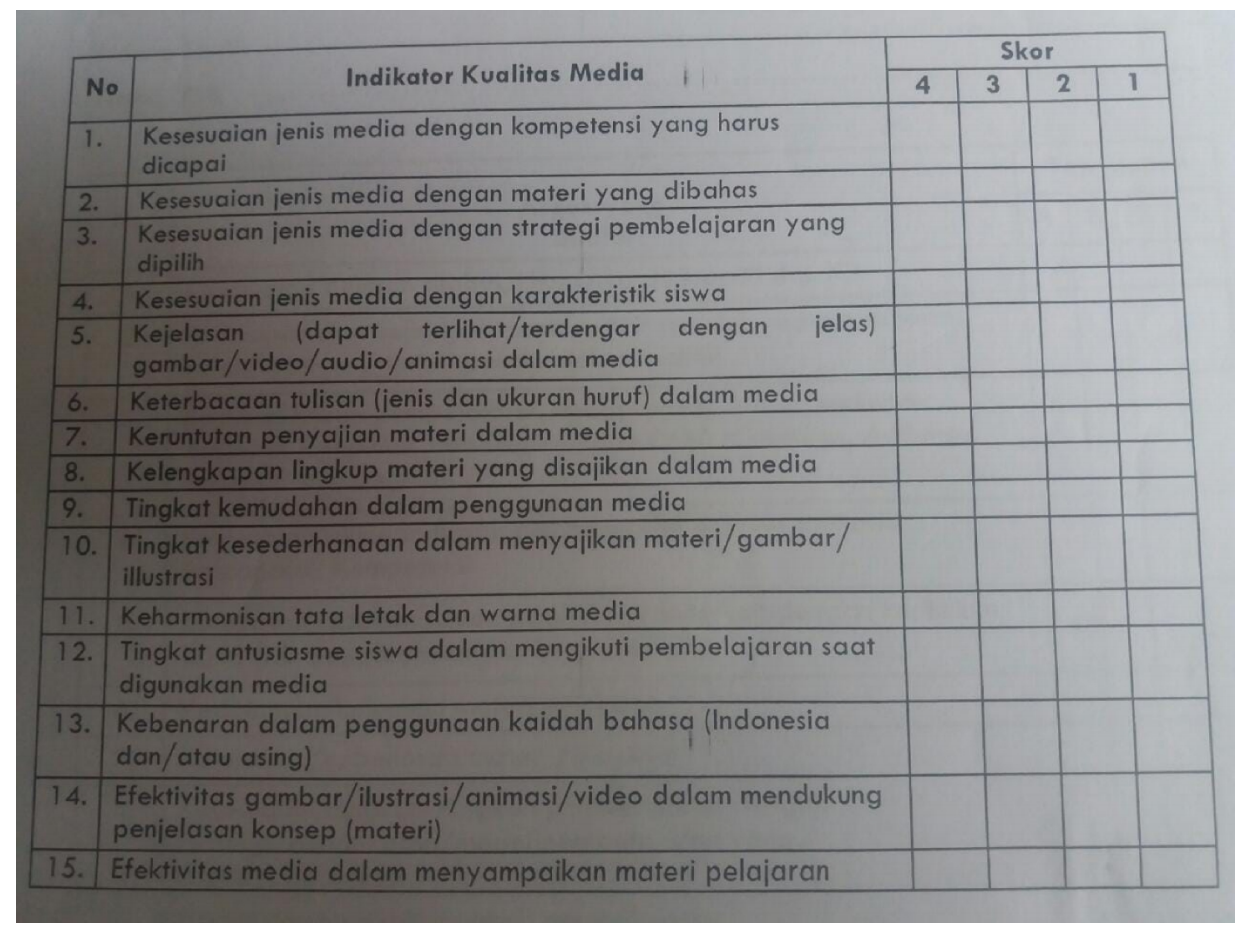

The 4-1 score stated on the form is a measure $(4=$ very good, $3=\operatorname{good}, 2=$ not bed, and $1=$ not good).

\section{Result And Discussion}

\subsection{Creativity creates active learning}

Being a good teacher is not enough. The researcher cited the opinion [4], that reinforces this, namely that a teacher is not only good, but also must be awesome. Among the characteristics that are possessed include: (1) an awesome teacher knows how to work the mind, so it is not only good at talking; (2) an amazing teacher has sensitivity, so it does not only have a methodology; (3) a teacher wonderfully educating emotions, so not only educating logical intelligence; (4) awesome teachers will use memory as a supporter of the art of thinking, so not only use memory as a store of information; (5) awesome teachers are unforgettable leaders, so not leaders while. Therefore, through observations that are restricted to religious teachers, the researchers directly observed teacher activities at Daarul Himmah MTs who were carrying out classroom learning. Delivering the material "Al-Azhar Growth and Development" on Islamic Culture History subjects, the teacher uses the method of "discussion, question and answer, recitation, presentation, zigshow" and presents the media in the form of paperboard that is distributed to each group of students and markers to write the results their group work, then pasted on the classroom wall. 
Active learning is created in learning, because every student actively engages in discussion in his group and tries to write the results of his team's work on paperboard given neatly and systematically by the teacher in accordance with the LKPD (Student Worksheet) given by the teacher. "LKPD" in question is a description of activities that will be carried out by discussion groups with instructions on how to do the work done by the teacher along with the items about knowledge or knowledge.

The researcher observes the teaching creativity of the teacher in class VIII is a religious teacher because it is related to the label of this school namely Madrasah Tsanawiyah. Another limitation in this study is about the data of the teacher being observed is the practitioner who is placed as a teacher of Field Experience Practices for the Indonesian teacher certification program. An opportunity to see and review concretely the conditions of schooling in this country. The teacher's competence with the situation of students who live in the information era.

The following are observations that contain portraits of media use in classroom learning, presentations of students in front of the class as a mirror of the use of varied methods in learning and the number of students in one class along with religious teachers who deliver material during ongoing observations and mosque conditions.

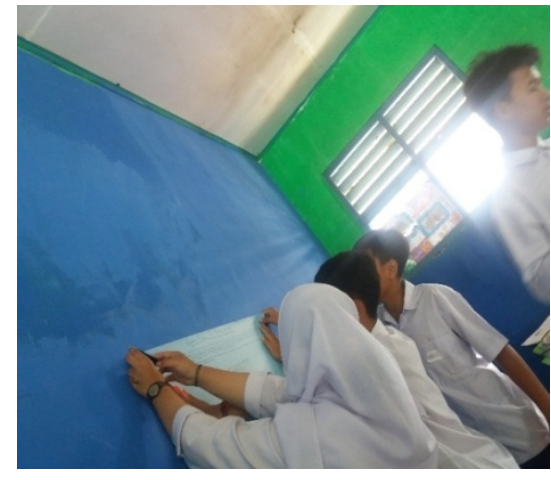

Figure 1.

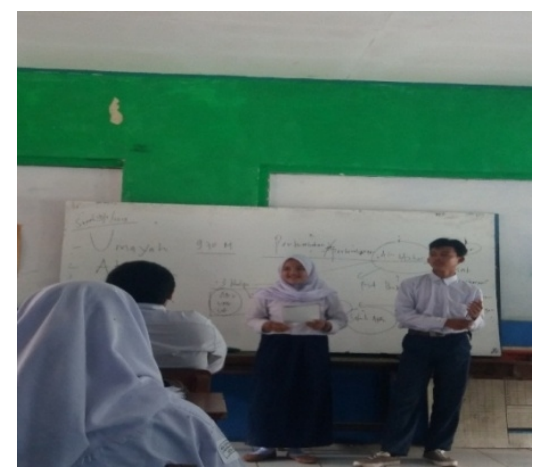

Figure 3.

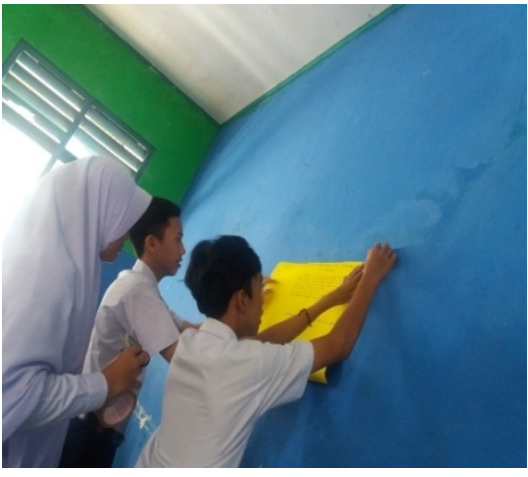

Figure 2.

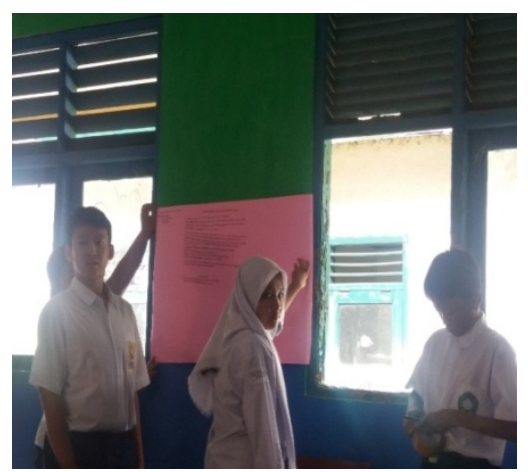

Figure 4. 


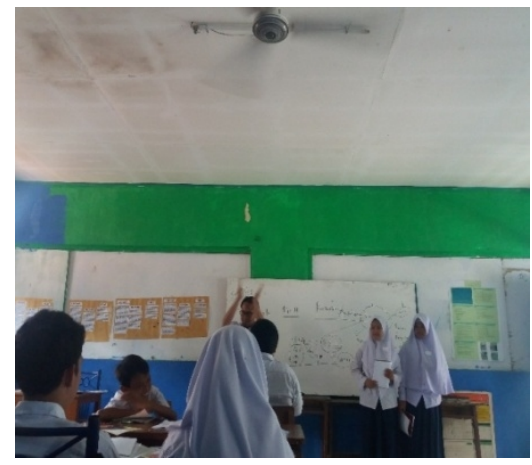

Figure 5.

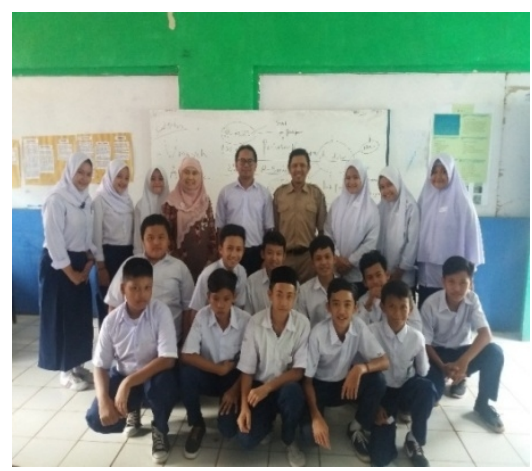

Figure 7.

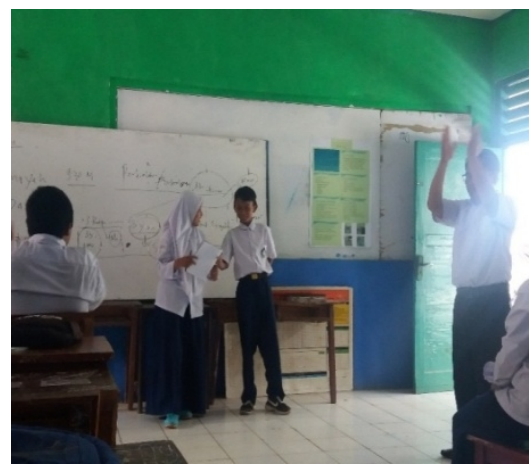

Figure 6.

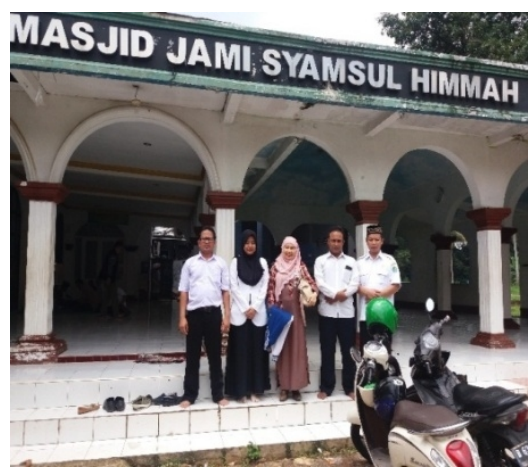

Figure 8.

The eight images above show that the small number of students is an indication that the interest of the community to enter their children into school is not so enthusiastic. However, the positive side is that it becomes an ideal condition for classroom learning so that a teacher is easier to conduct classroom management when the number of students is not too much or often referred to as "small class".

Likewise the competence of the teacher or practitioner observed in this study becomes very maximal in applying learning methods so students are not saturated and active learning is created. It appears that the teacher clapped his hands to give appreciation to the students who had presented the results of their group work in front of the class. The work of groups of students to post the results of their discussion on the classroom walls shows that active learning is carried out as the objectives have been made in the RPP (Learning Implementation Plan).

\subsection{Limited facilities and infrastructure}

Adequate learning facilities and infrastructure are one of the supporting factors for success in learning. As stated by Ramayulis, that we can distinguish "three environments as 
learning resources, namely: first, Open Environment, second: Historical Environment or Historical Heritage, and third: Human Environment or Community Environment", [5].

The definition of an open environment is nature itself without the presence of "humans". Children can know and enjoy nature so that they can see, feel and enjoy the majesty of God. Children can find something new from the life of God's creatures to thank Him. Currently there are many educational institutions, both formal and non-formal, that use learning methods with the environment. For example, out of bond activities, this activity directly introduces children to their environment. That way children will get diverse knowledge and information. For example, how to care for the environment, love animals and others, so that good habits like this will shape their character. In addition there are educational institutions "School of Nature". In this institution the more dominant learning activities are carried out outside the classroom, with the aim of being able to receive information while enjoying the beauty of nature.

Second, Historical Environment or Historical Heritage. The purpose of the historical environment is in the form of historical places and historical relics that have been arranged like a museum. From this natural environment can obtain iktibar or teaching so that students obtain new values for themselves. In the introduction of this historical environment study tour activities are usually held, namely learning and traveling. For example activities visiting temples, museums, palaces and others. Education like this indirectly can also increase the religious value of students that is understanding the sign of the greatness of God through His creation.

Third, Nature of the Human Environment or Community Environment. The community environment from the smallest is family to the educational environment. The influence of the community on children is very large. Especially the influence of the family environment. Diverse influences do not always benefit children. Thus its use as a learning resource must be selective. For that people should create a good environment by doing good habits so that it can be a source of learning for children. Because children's age is their dominant learning process is to imitate the habits of the people they see. By seeing good habits, the hope is that children do good things too.

In contrast to Prayitno in a book entitled "Basic Theory and Praxis of Education" states, "the learning environment consists of the physical environment, socio-emotional relationships, the environment of peers and neighbors, the dynamic environment of society in general, and foreign environmental influences", [6]. One of the environments mentioned is the physical environment which includes the condition of the home environment, the school environment and the distance between home and school. 1) Home environment. The comfort and health conditions of a residence can have an impact on the learning process of a student. The condition of the home environment directly affects one's learning activities when in his residence. 2) School environment. The condition of the school environment basically consists of environmental conditions in the classroom and the environment outside the classroom. Environmental conditions in the classroom for example, the seating position of students can influence concentration and the comfort of the learning process. This is related to the ergonomics of students. Ergonomics is the study of the application of technological rules to equipment used for the suitability and balance of humanity's life, both in activity and rest towards improving the quality of life. The comfort conditions not only lie in the learning facilities, but also the condition of the building as a whole and its equipment. 3) Distance between home and school. The distance between home and school can affect the learning process of students. The delay or fatigue of a person due to the distance of a remote residence can disrupt concentration in the learning process. 
Having an infocus or LCD in each class is a common sight in the information age at each school that carries out classroom learning. However, at the Daarul Himmah MTs, this is not the case. It has a size of land of $2000 \mathrm{~m}^{2}$ with a total of 6 classrooms measuring $8 \times 7=56 \mathrm{~m}^{2}$ and squeezed by residents' houses and surrounded by fish ponds which are the business or business of the surrounding economy. A library whose existence is like a warehouse because it is dusty and does not function optimally and the absence of a parking area, makes this school seem powerless to improve the facilities needed. For this reason, the strongest reason for the researcher to describe this paper is to illustrate the teacher's competence in managing learning in a class with limited facilities and infrastructure. As Sugiyanto argues, "the professionalism of a teacher is not in his ability to develop knowledge, but rather in his skills to carry out interesting and meaningful learning for students, including mastering the theory and practice of contextual learning", [7].

The school environment "Darul Himmah MTs" is equipped with a mosque building covering $375 \mathrm{~m}^{2}$ which is used by Madrasah Ibtidaiyah as well and coincides with the location of the MI so that MTs classrooms (classes VII and VIII) are also on the second floor of this school building. However, the enthusiasm of the teachers and students in the daily activities of learning makes this school still exist today. The problem of parking is limited because the layout of the school environment that coincides with the houses of residents makes the guardians of students or registrants when PPDB (New Student Admission) seem uncomfortable so many are turning to find other school locations. For this reason, the interest of applicants who enter the school is generally the community with jobs as fish farmers, laborers and employees. In other words, the economic conditions of the parents of Darul Himmah students belong to the lower middle class. Other evidence is that the students at MTs Daarul Himmah who were closest to their homes with schools, named Adinda Kls VII, Halimah Tussa'diyah Kls VIII, and Ayu Cantika Kls IX.

\section{Conclusion}

\subsection{Conclusion}

- Creativity is the positive energy needed in a situation that has certain limitations. As the Darul Himmah MTs school with facilities and infrastructure that are incomplete or can be called "minimal" can still be held active learning process until now.

- The competence of the teacher or practitioner in class management and varying the various methods in learning is a necessity to answer the challenges of the conditions that exist in Darul Himmah MTs.

\subsection{Suggestions}

- This research is a small part of the portrait of education in this country, let's continue to improve the quality of education from various sides.

- It is never too late to pay more attention to the real conditions of our country, especially in the field of education.

\section{Reference}

[1] Febrialismanto, Jurnal Pendidikan Anak. https://journal.uny.ac.id/index.php/jpa/article/view/17700, diakses 14 Maret 2019. Pukul. 23.35 wib. 
[2] Lexy J. Moleong, Metodologi Penelitian Kualitatif. Bandung: PT Remadja Rosdakarya, Edisi Revisi. h.6, 2009.

[3] Poerwandari dalam Imam Gunawan, Metode Penelitian Kualitatif: Teori dan Praktik. Jakarta: Bumi Akara. hlm. 143, 2013.

[4] Augusto Cury, Briliant Parents Fascinating Teachers; Kiat Membentuk Generasi Muda yang Cerdas dan Bahagia. Jakarta: Gramedia Pustaka Utama. hlm. 47-72, 2007.

[5] Ramayulis. Metodologi Pendidikan Agama Islam. Jakarta: Kalam Mulia, 2008.

[6] Prayitno. Dasar Teori dan Praksis Pendidikan. Jakarta: Grasindo. h.362, 2009.

[7] Sugiyanto dalam buku "Model-Model Pembelajaran Inovatif" (2010: 14-175) dalam Abuddin Nata, Pengembangan Profesi Keguruan dalam Perspektif Islam. Depok: Raja Grafindo Persada, cet. ke-1, 2019. 